\title{
A Hybrid Synthetic Pathway for Butanol Production by a Hyperthermophilic Microbe
}

\author{
Matthew W. Keller ${ }^{1}$, Gina L. Lipscomb ${ }^{1}$, Andrew J. Loder ${ }^{2}$, Gerrit J. Schut ${ }^{1}$, Robert M. Kelly ${ }^{2}$
} and Michael W. W. Adams ${ }^{1 *}$

\author{
${ }^{1}$ Department of Biochemistry \& Molecular Biology, University of Georgia, \\ Athens, GA 30602 \\ ${ }^{2}$ Department of Chemical and Biomolecular Engineering, \\ North Carolina State University, Raleigh, NC 27695
}

*To whom correspondence should be addressed (email: adams@bmb.uga.edu) 


\begin{abstract}
Biologically produced alcohols are of great current interest for renewable solvents and liquid transportation fuels. While bioethanol is now produced on a massive scale, butanol has superior fuel characteristics and additional value as a solvent and chemical feedstock. Butanol production has been demonstrated at ambient temperatures in metabolically-engineered mesophilic organisms, but the ability to engineer a microbe for in vivo high-temperature production of commodity chemicals has several distinct advantages. These include reduced contamination risk, facilitated removal of volatile products, and a wide temperature range to modulate and balance both the engineered pathway and the host's metabolism. We describe a synthetic metabolic pathway assembled from genes obtained from three different sources for conversion of acetylCoA to 1-butanol, and 1-butanol generation from glucose was demonstrated near $70^{\circ} \mathrm{C}$ in a microorganism that grows optimally near $100^{\circ} \mathrm{C}$. The module could also be used in thermophiles capable of degrading plant biomass.
\end{abstract}

\title{
Keywords
}

butanol, biofuels, hyperthermophile, module, hybrid, pathway 


\section{Introduction}

Butanol as an advanced biofuel has several advantages over ethanol. It has a greater energy density, can be used in higher blend ratios, and is more compatible with the current infrastructure for transportation (Atsumi and Liao, 2008; Peralta-Yahya and Keasling, 2010; Peralta-Yahya et al., 2012; Zhang et al., 2011). For this reason, a significant amount of research has been directed toward microbial production of butanol and so-called 'advanced biofuels', by metabolically-engineered mesophilic organisms (Lan and Liao, 2013). High titers (30 g/L) of 1butanol from glucose have been achieved by a heavily engineered strain of Escherichia coli with in situ product removal (Shen et al., 2011). Butanol and isobutanol have also been generated at ambient temperature using carbon dioxide as the carbon source in the mesophilic bacteria Clostridium ljungdahlii (Köpke et al., 2010), Synechoccoccus elongates (Lan and Liao, 2012) and Ralstonia eutropha (Li et al., 2012). While platform microorganisms that thrive at extreme temperatures offer potentially critical advantages for biofuel production (Abdel-Banat et al., 2010; Basen et al., 2012; Cripps et al., 2009; Keller et al., 2013), few thermophilic organisms have been engineered for butanol production: increased butanol in Thermoanaerobacterium thermosaccharolyticum (formerly Clostridium thermosaccharolyticum) at $55^{\circ} \mathrm{C}$ by overexpression of the native bcs operon (Bhandiwad et al., 2013), Thermoanaerobacterium saccharolyticum at $55^{\circ} \mathrm{C}$ by expression of the butanol pathway from the closely related $T$. thermosaccharolyticum (Bhandiwad et al., 2014), and isobutanol production from Geobacillus thermoglucosidasius at $50^{\circ} \mathrm{C}$ by expressing and optimizing an isobutanol pathway from multiple gene donors (Lin et al., 2014).

Metabolic engineering of thermophilic microorganisms for the production of a variety of useful chemicals such as polymer feedstocks and liquid transportation fuels has traditionally 
been limited by the availability of genetically tractable model organisms. Within the last decade, however, genetic capabilities have been developed for several that grow at $85^{\circ} \mathrm{C}$ and above (Kim et al., 2010; Lipscomb et al., 2011; Sato et al., 2003). An advantage of using a thermophilic organism for metabolic engineering is the possibility of utilizing temperature as a way to modulate and balance both the engineered pathway and the host's metabolism. This novel concept has been demonstrated in the hyperthermophile Pyrococcus furiosus, which has an optimal growth temperature $\left(\mathrm{T}_{\mathrm{opt}}\right)$ of $100^{\circ} \mathrm{C}$, by the heterologous expression of lactate dehydrogenase from Caldicellulosiruptor bescii $\left(\mathrm{T}_{\mathrm{opt}} 78^{\circ} \mathrm{C}\right)$ using a low temperature $\left(72^{\circ} \mathrm{C}\right)$ shift to induce lactate formation (Basen et al., 2012). P. furiosus has also been engineered to utilize hydrogen and incorporate carbon dioxide into the valuable molecule 3-hydroxypropionate using a similar strategy for temperature-dependent product formation (Keller et al., 2013). Herein we demonstrate metabolic engineering of $P$. furiosus for the temperature-dependent production of the liquid fuel and chemical feedstock 1-butanol.

\section{Material and methods}

\subsection{Strain construction.}

The pathway genes for BuOH-1 ( $t h l$, TTE0549; $h b d$, TTE0548; crt, TTE0544; ter, Stherm_c16300; bad, Teth514_1942; bdh, Teth514_1935) and the genes for BuOH-2 (thl; hbd; crt; ter; adhE, Teth514_0627; adhA, Teth514_0564) were assembled into artificial operons (see Fig. 1b). The ter gene was codon optimized for P. furiosus (Genewiz, Inc., South Plainfield, NJ) and the sequence is given in Supplementary Table 1. The operon was driven by the promoter of the gene encoding the gamma subunit of pyruvate oxidoreductase (175 bp immediately upstream of PF0971, including its ribosomal binding site) and terminated with 19 bases of the 3' UTR of 
the hpyAl gene (5'- aatctttttagcactttt, locus PF1722). P. furiosus ribosomal binding sites (RBSs) consisting of 12-14 bp of sequence upstream of genes encoding highly expressed proteins were placed upstream of each internal gene using primer tails as follows: the RBS for highly expressed S-layer protein (5'-ggaggtggagaaaa) was placed in front of ter and $h b d$ and the RBS for the highly expressed PEP synthase (5'-ggaggtttgaag) was placed in front of and $b d h$ or $a d h A$, thl and crt. Gibson Assembly (Merryman and Gibson, 2012) was used to assemble the $\mathrm{BuOH}$ expression constructs into the vector pGL050 containing the $p y r F$ genetic marker and flanking regions to delete ACSI $\alpha$ (PF1540) (Thorgersen et al., 2014), generating pGL053 and pGL056 (for BuOH-1 and BuOH-2, respectively Supplementary Fig. 1). Plasmids were sequenceverified and pGL056 was found to contain a single point mutation in the RBS in front of adhA, which may be inconsequential. Plasmids were linearized and used to transform $P$. furiosus COM1 according to previously described methods (Lipscomb et al., 2011). Transformants were colony-purified and strains were designated as follows: MW164 (pGL053 transformant) and MW196 (pGL056 transformant). These are herein referred to as the BuOH-1 and BuOH-2 strains, respectively (Supplementary Table 2).

\subsection{Growth of $P$. furiosus.}

Strains were cultured as previously described in a sea-water based medium containing $5 \mathrm{~g} / \mathrm{L}$ maltose and $5 \mathrm{~g} / \mathrm{L}$ yeast extract, $0.5 \mu \mathrm{g} / \mathrm{L}$ riboflavin, and $20 \mu \mathrm{M}$ uracil (Adams et al., 2001; Basen et al., 2012). Cultures were grown at $98^{\circ} \mathrm{C}$ to $\sim 1 \times 10^{8}$ cells $/ \mathrm{mL}$ and then transferred to a water bath calibrated to 50 to $70^{\circ} \mathrm{C}$, which was maintained for up to $72 \mathrm{~h}$. For growth in a $15 \mathrm{~L}$ fermenter, the culture was sparged with $10 \% \mathrm{CO}_{2} / 90 \% \mathrm{~N}_{2}$, stirred, and the $\mathrm{pH}$ was maintained at 6.8 by addition of $10 \% \mathrm{NaHCO}_{3}$. The cultures were harvested by centrifugation at $6,000 \mathrm{x} g$ for $10 \mathrm{~min}$. Cell extracts were prepared anaerobically by sonicating the cell pellets in $100 \mathrm{mM}$ 
MOPS, $\mathrm{pH} 7.5$, ultracentrifugation at 100,000 $\mathrm{x} g$ for 60 minutes, washing and re-concentrating three-times with a $10 \mathrm{kDa}$ centrifugation filter and storing in sealed vials at $-80^{\circ} \mathrm{C}$.

\subsection{RNA extraction and quantitative RT-PCR analyses.}

RNA was extracted from $10 \mathrm{~mL}$ samples of culture using the Direct-zol ${ }^{\mathrm{TM}}$ RNA MiniPrep kit (Zymo Research). Genomic DNA was digested using TURBO DNase (Ambion) and further purified by phenol:chloroform extraction and precipitation. Synthesis of cDNA was performed with $1 \mu \mathrm{g}$ purified RNA using the Affinity Script QPCR cDNA synthesis kit (Agilent). The Brilliant III SYBR® Green QPCR Master Mix (Agilent) was used for quantitative RT-PCR experiments using an MX3000P instrument (Stratagene). Primers were designed to amplify a $\sim 150 \mathrm{~b}$ product within the target gene, including PF0971 ( $P$. furiosus POR $\gamma$ control gene), bad, bdh, adhE, adhA, codon-optimized ter, thl, hbd, and crt.

\subsection{NADH dependent enzyme assays.}

All reactions were carried out in sealed anaerobic cuvettes at $60^{\circ} \mathrm{C}$ (unless otherwise indicated) containing $25 \mathrm{mM}$ MOPS pH 7.5. Extract was added to a final concentration of $0.2 \mathrm{mg} / \mathrm{mL}$ and $\mathrm{NADH}$ to $\mathrm{A}_{340} \sim 1.0$. After addition of the relevant substrate, NADH oxidation was measured at $340 \mathrm{~nm}$. The relevant substrates for the Thl+Hbd, Hbd, Ter, Bad, and Bdh assays are acetylCoA, acetoacetyl-CoA, crotonyl-CoA, butyryl-CoA, and butyraldehyde respectively.

\subsection{In vitro Butanol production.}

All reactions were carried out in sealed anaerobic vials at $60^{\circ} \mathrm{C}$ (unless otherwise indicated) containing $100 \mathrm{mM}$ MOPS pH 7.5 and $5 \mathrm{mM} \mathrm{MgCl}_{2}$. Extract was added to a final concentration of $2.0 \mathrm{mg} / \mathrm{mL}$. NADH and the indicated substrates were added to a butanol theoretical yield of $1 \mathrm{mM}$. Acetyl-CoA was added to assay the entire synthetic pathway, butyryl-CoA was added to 
assay Bad+Bdh, and butyraldehyde was added to assay Bdh. Samples were acidified to $8 \%$ formic acid and analyzed via gas chromatography flame ionization detection.

\subsection{In vivo butanol production.}

P. furiosus strains COM1, MW164, and MW196 were grown in $1 \mathrm{~L}$ cultures in sealed bottles at $98^{\circ} \mathrm{C}$ until the cell density reached $8 \times 10^{7}$ cells $/ \mathrm{mL}$. They were then incubated at $60^{\circ} \mathrm{C}$ for $72 \mathrm{~h}$ for enzyme expression. After the enzyme expression, the cultures were harvested and suspended in sea-water based salts with the addition of $100 \mathrm{mM}$ MOPS (pH 7.5) and $50 \mathrm{~g} / \mathrm{L}$ maltose. Cells from each $1 \mathrm{~L}$ culture were suspended in $5 \mathrm{~mL}$ so that the cell density was concentrated to $\sim 200 \mathrm{x}$ the original culture density. The suspensions were then incubated at $60^{\circ} \mathrm{C}$ for product formation. Aliquots of $250 \mu \mathrm{L}$ were centrifuged, and the supernatants were acidified to $\mathrm{pH} 2$ using formic acid and analyzed via gas chromatography flame ionization detection. Maltose consumption was estimated by the production of acetate, ethanol and butanol assuming stoichiometric ratios of 1:4, 1:4 and 1:2, respectively.

\section{Results and Discussion}

\subsection{Design of the hybrid synthetic pathways}

$P$. furiosus is a genetically tractable marine anaerobe that has an optimal growth temperature $\left(\mathrm{T}_{\mathrm{opt}}\right)$ of $100^{\circ} \mathrm{C}$ and ferments carbohydrates and peptides (Fiala and Stetter, 1986; Lipscomb et al., 2011). The highest temperature at which engineered butanol formation has been reported is $55^{\circ} \mathrm{C}$ (Bhandiwad et al., 2013; Bhandiwad et al., 2014). To increase this temperature limit for butanol production in P. furiosus, genes were selected from three different organisms to assemble an artificial pathway that combines steps from a butyrate-forming fermentation pathway with aldehyde and alcohol dehydrogenases (Fig. 1a). The first three enzymes of the pathway convert acetyl-CoA to crotonyl-CoA and are derived from the fermentative bacterium 
Thermoanaerobacter tengcongensis, $\left(\mathrm{T}_{\mathrm{opt}} 75^{\circ} \mathrm{C}\right)$ (Xue et al., 2001). The reduction of crotonylCoA to butyryl-CoA is carried out by the enzyme trans-2-enoyl-CoA reductase (Ter). $T$. tengcongensis contains a homolog of this enzyme, but it is a complex electron-bifurcating enzyme that requires two equivalents of $\mathrm{NADH}$ and produces reduced ferredoxin in addition to reducing crotonyl-CoA (Li et al., 2008; Shen et al., 2011). We, therefore, chose the enzyme Ter from Spirochaeta thermophila, a fermentative bacterium that grows optimally at $65^{\circ} \mathrm{C}$ (Aksenova et al., 1992), as it requires only one equivalent of NADH as substrate and has the added benefit of being irreversible (Shen et al., 2011). For the conversion of butyryl-CoA to butanol we chose to follow two strategies. For one pathway, butyraldehyde dehydrogenase (Bad) and butanol dehydrogenase (Bdh) were selected from Thermoanaerobacter sp. X514 $\left(\mathrm{T}_{\mathrm{opt}} 65^{\circ} \mathrm{C}\right)$ (Roh et al., 2002). These are both previously uncharacterized from this organism but together should reduce the CoA derivative to the alcohol, equivalent to the bi-functional enzyme alcohol dehydrogenase E (AdhE) (Extance et al., 2013). Bad and Bdh have homology to the two domains of AdhE, which are an aldehyde dehydrogenase and an iron containing alcohol dehydrogenase. The pathway containing Bad and Bdh is designated as the BuOH-1 pathway. For comparison, we also constructed a pathway, termed $\mathrm{BuOH}-2$, containing the bi-functional AdhE along with alcohol dehydrogenase A (AdhA), both from Thermoanaerobacter sp. X514 (Fig. 1a).

The pathway genes were assembled into synthetic operons, driven by the strong constitutive promoter of the gene encoding the $\gamma$ subunit of pyruvate oxidoreductase (POR) of $P$. furiosus (Fig. 1b). Ribosomal binding sites of highly expressed $P$. furiosus proteins were included between each gene for optimal protein production, along with a terminator sequence from P. furiosus at the end of the operon. A codon-optimized version of the Ter gene was used 
because the GC content of $S$. thermophila (61.9\%) was significantly higher than $P$. furiosus $(40.8 \%)$.

\subsection{Modifying native $P$. furiosus metabolism}

The butanol pathway expression constructs were inserted into the $P$. furiosus chromosome to simultaneously delete the alpha subunit of acetyl-CoA synthase I (ACSI), generating the $\mathrm{BuOH}-1$ and $\mathrm{BuOH}-2$ strains (Supplementary Table 2). ACSI is one of two major enzymes responsible for conversion of acetyl-CoA to acetate (Mai and Adams, 1996); therefore, the $\mathrm{BuOH}$ strains are designed to redirect acetyl-CoA away from acetate production and into the butanol pathway. While the effect of this knockout on butanol production was not determined here, a knockout of ACSI $\alpha$ was previously shown to improve production of 3hydroxypropionate in an engineered $P$. furiosus strain (Thorgersen et al., 2014). This is an analogous strategy as both the butanol and 3-hydroxypropionate pathways utilize acetyl-CoA as their primary carbon substrate.

\subsection{Expression strategy for the fuel pathway}

We performed quantitative PCR to determine expression levels of the $\mathrm{BuOH}-1$ and $\mathrm{BuOH}-2$ pathways at 98, 65 and $60^{\circ} \mathrm{C}$ (Supplementary Figure 2). The expression levels of the genes in the synthetic operons are similar between the two strains, and they are within an order of magnitude of the native host gene encoding the gamma subunit of the glycolytic enzyme pyruvate ferredoxin oxidoreductase, whose promoter was used to drive expression of the pathways.

Expression of active heterologous enzymes that yield a functional butanol pathway in $P$. furiosus is dependent on growth temperature as the genes are derived from organisms with lower optimal growth temperatures than the host. At $98^{\circ} \mathrm{C}$ they are all expected to be inactive, hence 
growth of the $P$. furiosus $\mathrm{BuOH}-1$ strain at this temperature results in wild type metabolism and the production of acetate (via other ACS homologs), carbon dioxide and hydrogen from sugar (the disaccharide, maltose). A shift to a lower temperature would lead to the production of active forms of the butanol pathway enzymes that together should divert acetyl-CoA to butanol. The net result is one molecule of glucose yielding two molecules of carbon dioxide and one molecule of butanol (Supplementary Fig. 3).

\subsection{In vitro characterization of $\mathrm{BuOH}-1$ and $\mathrm{BuOH}-2$}

The butanol pathways were assembled from three different gene donors with optimal growth temperatures ranging from $60-75^{\circ} \mathrm{C}$. To determine if active forms of the heterologouslyexpressed enzymes were produced in P. furiosus, the $\mathrm{BuOH}-1$ strain was grown to mid-log phase at $98^{\circ} \mathrm{C}$, near the optimal temperature of the host, and then shifted to temperatures ranging from $50^{\circ} \mathrm{C}$ to $70^{\circ} \mathrm{C}$. The cytosolic extracts were assayed to determine if butanol could be produced in vitro at $60^{\circ} \mathrm{C}$, the lowest optimal growth temperature of the three gene donors. As shown in Fig. 2a, butanol was produced from extracts of cells shifted to all temperatures tested for $\mathrm{BuOH}-1$, but activity was extremely low in $\mathrm{BuOH}-2$. The highest specific activity for butanol formation was in the 60 to $65^{\circ} \mathrm{C}$ range. To compare $\mathrm{C} 4$ specificity in the $\mathrm{BuOH}-1$ versus $\mathrm{BuOH}-2$ strain (Fig. 1b), cytosolic extracts from both strains were prepared following heterologous expression at $60^{\circ} \mathrm{C}$. Along with parental strain COM1, cell-extracts were prepared and were assayed at $60^{\circ} \mathrm{C}$ for NADH dependent activity on crotonyl-CoA (Ter), butyryl-CoA (Bad), and butyraldehyde (Bdh) (Fig. 2b). While the Ter activities for both recombinant strains are nearly identical, extracts of the strain $\mathrm{BuOH}-1$ shows higher activity on the $\mathrm{C}-4$ substrates, particularly in the final step that converts butyraldehyde to butanol. Hence, in the following we focus on P. furiosus strain $\mathrm{BuOH}-1$ for more in depth characterization. 
Specific activities were determined for individual enzymes or sets of enzymes in the $\mathrm{BuOH}-1$ strain at various assay temperatures using cell extracts prepared from cells shifted to $60^{\circ} \mathrm{C}$ (Fig. 3a-f). In P. furiosus extracts, the Thl and Hbd enzymes from T. tengcongensis (Fig. 3a, b) exhibited maximal activity at or above $80^{\circ} \mathrm{C}$, which is not surprising as this is the gene donor with the highest optimal growth temperature $\left(75^{\circ} \mathrm{C}\right)$. Temperatures above $80^{\circ} \mathrm{C}$ were not assayed because of the instability of the substrate. The Ter enzyme showed maximal activity at $60^{\circ} \mathrm{C}$ (Fig. 3c), consistent with the optimal growth temperature of S. thermophila $\left(60-65^{\circ} \mathrm{C}\right)$. The Bad and Bdh enzymes exhibited broader temperature ranges for activity, and background Bdh activity was observed from the $P$. furiosus parent strain at the higher assay temperatures (Fig. 3d, e). For the complete pathway, the in vitro conversion of acetyl-CoA and NADH to butanol was optimal at $60^{\circ} \mathrm{C}(\mathbf{F i g} . \mathbf{3 f})$, and this is most likely limited by the optimal temperature for activity of either the Ter or Bdh enzyme.

\subsection{In vivo demonstration of $\mathrm{BuOH}-1$ and $\mathrm{BuOH}-2$}

To demonstrate in vivo butanol production in $P$. furiosus and to further compare the use of $\mathrm{Bad}$ and $\mathrm{Bdh}$ in the $\mathrm{BuOH}-1$ strain versus AdhE and AdhA in the $\mathrm{BuOH}-2$ strain, concentrated cell suspensions $\left(\geq 10^{10}\right.$ cells/mL) of both strains, along with the parental strain COM1, were prepared in the presence of maltose and incubated at $60^{\circ} \mathrm{C}$. The cell suspensions were analyzed for butanol, acetate, and ethanol at various time points up to $48 \mathrm{~h}$ (Fig. 4). In strain BuOH-1 extracellular butanol (Fig. 4a) production reached a maximum of $\sim 70 \mathrm{mg} / \mathrm{L}$ after $48 \mathrm{~h}$, which corresponds to $5 \%$ of theoretical yield based on the maltose that was consumed (Fig. 4b). The strain $\mathrm{BuOH}-2$ had much lower productivity as it produced $15 \mathrm{mg} / \mathrm{L}$ butanol after 48 hrs, which corresponds to $1 \%$ of the maximal theoretical yield (Fig. $\mathbf{4 b}$ ). In addition, production of ethanol and acetate were analyzed (Fig. 4c-d). While no difference was observed in acetate 
formation, ethanol production was tripled from $500 \mathrm{mg} / \mathrm{L}$ to $1500 \mathrm{mg} / \mathrm{L}$ in the $\mathrm{AdhE}$ and AdhA containing strain $\mathrm{BuOH}-2$. The strain $\mathrm{BuOH}-1$ showed little to no increase in ethanol production compared to the parental strain COM-1. These results, along with the in vitro data presented in Figure 2, demonstrates that the use of the $b a d$ and $b d h$ genes for butanol production is superior to the use of AdhE and AdhA.

\section{Conclusion}

We have demonstrated butanol production in a hyperthermophilic archaeon, using an artificial pathway assembled from three gene donors having moderate differences in growth temperature optima. Furthermore, the $\mathrm{BuOH}-1$ pathway can utilize acetyl-CoA from the host metabolism, which is operating at close to $40^{\circ} \mathrm{C}$ below its optimal temperature. A fuel module such as this can be combined with a more advanced strategy in which $\mathrm{H}_{2}$ and $\mathrm{CO}_{2}$ can be used to supply acetyl-CoA in place of host sugar metabolism (Hawkins et al., 2011; Keller et al., 2013). The module may also be used in other genetically tractable thermophilic microbes, in particular, those that have slightly lower growth temperature optima than $P$. furiosus and may be more suited for expression of a pathway at $60^{\circ} \mathrm{C}$ (Atomi et al., 2004), or ones that are capable of degrading plant biomass (Basen et al., 2014). Such a strategy would couple the artificial fuel pathway to the native metabolism of the host and would have applications for consolidated bioprocessing of renewable biomass to a readily useable liquid transportation fuel. 


\section{References}

Abdel-Banat, B. A., Hoshida, H., Ano, A., Nonklang, S., Akada, R., 2010. High-temperature fermentation: how can processes for ethanol production at high temperatures become superior to the traditional process using mesophilic yeast? Appl Microbiol Biotechnol. 85, 861-867.

Adams, M. W. W., Holden, J. F., Menon, A. L., Schut, G. J., Grunden, A. M., Hou, C., Hutchins, A. M., Jenney, F. E., Kim, C., Ma, K. S., Pan, G. L., Roy, R., Sapra, R., Story, S. V., Verhagen, M. F. J. M., 2001. Key role for sulfur in peptide metabolism and in regulation of three hydrogenases in the hyperthermophilic archaeon Pyrococcus furiosus. J Bacteriol. 183, 716-724.

Aksenova, H. Y., Rainey, F. A., Janssen, P. H., Zavarzin, G. A., Morgan, H. W., 1992. Spirochaeta thermophila sp. nov., an obligately anaerobic, polysaccharolytic, extremely thermophilic bacterium. Int J syst Evol Bacteriol. 42, 175-177.

Atomi, H., Fukui, T., Kanai, T., Morikawa, M., Imanaka, T., 2004. Description of Thermococcus kodakaraensis sp. nov., a well studied hyperthermophilic archaeon previously reported as Pyrococcus sp. KOD1. Archaea. 1, 263-267.

Atsumi, S., Liao, J. C., 2008. Metabolic engineering for advanced biofuels production from Escherichia coli. Curr Opin Biotech. 19, 414-419.

Basen, M., Rhaesa, A. M., Kataeva, I., Prybol, C. J., Scott, I. M., Poole, F. L., Adams, M. W. W., 2014. Degradation of high loads of crystalline cellulose and of unpretreated plant biomass by the thermophilic bacterium Caldicellulosiruptor bescii. Bioresource Technol. 152, 384-392.

Basen, M., Sun, J., Adams, M. W. W., 2012. Engineering a hyperthermophilic archaeon for temperaturedependent product formation. mBio. 3.

Bhandiwad, A., Guseva, A., Lynd, L., 2013. Metabolic engineering of Thermoanaerobacterium thermosaccharolyticum for Increased n-butanol production. Adv Microbial. 3, 46-51.

Bhandiwad, A., Shaw, A. J., Guss, A., Guseva, A., Bahl, H., Lynd, L. R., 2014. Metabolic engineering of Thermoanaerobacterium saccharolyticum for n-butanol production. Metab Eng. 21, 17-25.

Cripps, R. E., Eley, K., Leak, D. J., Rudd, B., Taylor, M., Todd, M., Boakes, S., Martin, S., Atkinson, T., 2009. Metabolic engineering of Geobacillus thermoglucosidasius for high yield ethanol production. Metab Eng. 11, 398-408.

Extance, J., Crennell, S. J., Eley, K., Cripps, R., Hough, D. W., Danson, M. J., 2013. Structure of a bifunctional alcohol dehydrogenase involved in bioethanol generation in Geobacillus thermoglucosidasius. Acta Cryst D. 69, 2104-2115.

Fiala, G., Stetter, K., 1986. Pyrococcus furiosus sp. nov. represents a novel genus of marine heterotrophic archaebacteria growing optimally at $100^{\circ} \mathrm{C}$. Arch. Microbiol. 145, 56-61.

Hawkins, A. B., Han, Y., Lian, H., Loder, A., Menon, A. L., Iwuchukwu, I. J., Keller, M., Leuko, T., Adams, M. W., Kelley, R. M., 2011. Extremely thermophilic routes to microbial electrofuels. ACS Catalysis. 9, 1043-1050.

Keller, M. W., Schut, G. J., Lipscomb, G. L., Menon, A. L., Iwuchukwu, I. J., Leuko, T. T., Thorgersen, M. P., Nixon, W. J., Hawkins, A. S., Kelly, R. M., Adams, M. W. W., 2013. Exploiting microbial hyperthermophilicity to produce an industrial chemical, using hydrogen and carbon dioxide. PNAS. 110, 5840-5845.

Kim, Y. J., Lee, H. S., Kim, E. S., Bae, S. S., Lim, J. K., Matsumi, R., Lebedinsky, A. V., Sokolova, T. G., Kozhevnikova, D. A., Cha, S.-S., Kim, S.-J., Kwon, K. K., Imanaka, T., Atomi, H., BonchOsmolovskaya, E. A., Lee, J.-H., Kang, S. G., 2010. Formate-driven growth coupled with $\mathrm{H}_{2}$ production. Nature. 467, 352-355.

Köpke, M., Held, C., Hujer, S., Liesegang, H., Wiezer, A., Wollherr, A., Ehrenreich, A., Liebl, W., Gottschalk, G., Dürre, P., 2010. Clostridium ljungdahlii represents a microbial production platform based on syngas. PNAS. 107, 13087-13092. 
Lan, E. I., Liao, J. C., 2012. ATP drives direct photosynthetic production of 1-butanol in cyanobacteria. PNAS. 109, 6018-6023.

Lan, E. I., Liao, J. C., 2013. Microbial synthesis of n-butanol, isobutanol, and other higher alcohols from diverse resources. Bioresource Technol. 135, 339-349.

Li, F., Hinderberger, J., Seedorf, H., Zhang, J., Buckel, W., Thauer, R. K., 2008. Coupled ferredoxin and crotonyl coenzyme A (CoA) reduction with $\mathrm{NADH}$ catalyzed by the butyryl-CoA dehydrogenase/Etf complex from Clostridium kluyveri. J Bacteriol. 190, 843-850.

Li, H., Opgenorth, P. H., Wernick, D. G., Rogers, S., Wu, T.-Y., Higashide, W., Malati, P., Huo, Y.-X., Cho, K. M., Liao, J. C., 2012. Integrated electromicrobial conversion of $\mathrm{CO}_{2}$ to higher alcohols. Science. 335, 1596.

Lin, P. P., Rabe, K. S., Takasumi, J. L., Kadisch, M., Arnold, F. H., Liao, J. C., 2014. Isobutanol production at elevated temperatures in thermophilic Geobacillus thermoglucosidasius. Metab Eng. 24, 1-8.

Lipscomb, G. L., Stirrett, K., Schut, G. J., Yang, F., Jenney, F. E., Scott, R. A., Adams, M. W. W., Westpheling, J., 2011. Natural competence in the hyperthermophilic archaeon Pyrococcus furiosus facilitates genetic manipulation: construction of markerless deletions of genes encoding the two cytoplasmic hydrogenases. Appl Environ Microb. 77, 2232-2238.

Mai, X., Adams, M. W., 1996. Purification and characterization of two reversible and ADP-dependent acetyl coenzyme A synthetases from the hyperthermophilic archaeon Pyrococcus furiosus. J Bacteriol. 178, 5897-903.

Merryman, C., Gibson, D. G., 2012. Methods and applications for assembling large DNA constructs. Metab Eng. 14, 196-204.

Peralta-Yahya, P. P., Keasling, J. D., 2010. Advanced biofuel production in microbes. Biotechnol J. 5, 147162.

Peralta-Yahya, P. P., Zhang, F., del Cardayre, S. B., Keasling, J. D., 2012. Microbial engineering for the production of advanced biofuels. Nature. 488, 320-328.

Roh, Y., Liu, S. V., Li, G., Huang, H., Phelps, T. J., Zhou, J., 2002. Isolation and characterization of metalreducing Thermoanaerobacter strains from deep subsurface environments of the Piceance Basin, Colorado. Appl Environ Microb. 68, 6013-6020.

Sato, T., Fukui, T., Atomi, H., Imanaka, T., 2003. Targeted gene disruption by homologous recombination in the hyperthermophilic archaeon Thermococcus kodakaraensis KOD1. Journal of Bacteriology. $185,210-220$.

Shen, C. R., Lan, E. I., Dekishima, Y., Baez, A., Cho, K. M., Liao, J. C., 2011. Driving forces enable high-titer anaerobic 1-butanol synthesis in Escherichia coli. Appl Environ Microb. 77, 2905-2915.

Thorgersen, M. P., Lipscomb, G. L., Schut, G. J., Kelly, R. M., Adams, M. W. W., 2014. Deletion of acetylCoA synthetases I and II increases production of 3-hydroxypropionate by the metabolicallyengineered hyperthermophile Pyrococcus furiosus. Metab Eng. 22, 83-88.

Xue, Y., Xu, Y., Liu, Y., Ma, Y., Zhou, P., 2001. Thermoanaerobacter tengcongensis sp. nov., a novel anaerobic, saccharolytic, thermophilic bacterium isolated from a hot spring in Tengcong, China. Int J syst Evol Micr. 51, 1335-41.

Zhang, F., Rodriguez, S., Keasling, J. D., 2011. Metabolic engineering of microbial pathways for advanced biofuels production. Curr Opin Biotechnol. 22, 775-783. 


\section{Acknowledgments.}

This work was supported by the US Department of Energy as part of the Electrofuels project of ARPA-E (grant number DE-AR0000081).

\section{Author Contributions.}

R.M.K. and M.W.W.A. conceived of and managed the research; A.J.L. and G.L.L. performed operon design and construction, DNA cloning, and transformation of P. furiosus; M.W.K. and G.J.S. performed physiological and enzymatic analyses; M.W.K., G.L.L., R.M.K. and M.W.W.A. wrote the manuscript.

\section{Author Information.}

Correspondence and requests for materials should be addressed to M.W.W.A. (adams@bmb.uga.edu)

\section{Figure Legends}

Figure 1. The hybrid synthetic butanol pathway. (a) Diagram of the $\mathrm{BuOH}-1$ and $\mathrm{BuOH}-2$ pathways which use acetyl-CoA generated from the host's glycolytic pathway along with NADH to produce butanol. The pathways differ following the production of butyryl-CoA by the enzyme Ter. (b) Schematic diagram of the six gene synthetic operons for expressing the $\mathrm{BuOH}-1$ and BuOH-2 pathways, under control of the P. furiosus POR $\gamma$ promoter (bent arrow).

Figure 2. Comparioson of the $\mathrm{BuOH}-1$ and $\mathrm{BuOH}-2$ pathways and optimal temperature for the expression of the BuOH-1 pathway. (a) The rate of butanol formation from acetyl-CoA and $\mathrm{NADH}$ (nmol butanol/min/mg) measured in cytosolic extracts prepared from BuOH-1 (blue) and $\mathrm{BuOH}-2$ (red) grown to $1 \times 10^{8}$ cells $/ \mathrm{mL}$ at $98^{\circ} \mathrm{C}$ and shifted to the indicated temperature and 
incubated for 72 hours. (b) The NADH dependent activity $(\mu \mathrm{mol} / \mathrm{min} / \mathrm{mg}$ ) on crotonyl-CoA (Ter), butyryl-CoA (Bad), and butyraldehyde (Bdh) are compared in the strains BuOH-1 (blue), $\mathrm{BuOH}-2$ (red), and the parental strain COM1 (orange).

Figure 3. Optimal temperatures for activities of the BuOH-1 pathway enzymes. (a-e) Enzyme activities for pathway enzymes and reactions (shown in Fig. 1a) in the $\mathrm{BuOH}-1$ strain (blue) compared to the COM1 control strain (orange), assayed at the indicated temperatures. The strains were grown at $98^{\circ} \mathrm{C}$ to $1 \times 10^{8}$ cells $/ \mathrm{mL}$ and incubated at $60^{\circ} \mathrm{C}$ for $72 \mathrm{~h}$ in a $15 \mathrm{~L} \mathrm{pH}$ controlled fermenter. The individual enzyme rates ( $\mu \mathrm{mol} \mathrm{NADH}$ oxidation $/ \mathrm{min} / \mathrm{mg}$ ) were measured by the addition of acetyl-CoA for Thl+Hbd (a), acetoacetyl-CoA for Hbd (b), crotonyl-CoA for Ter (c), butyryl-CoA for Bad (d), and butyraldehyde for Bdh (e). (f) Specific butanol production from acetyl-CoA and NADH (nmol butanol/min/mg) for the complete pathway was measured in cytosolic extracts at the indicated temperatures.

Figure 4. In vivo butanol (a-b), acetate (c), and ethanol (d) production from maltose in $\mathrm{BuOH}-1$ (blue), $\mathrm{BuOH}-2$ (red), and $\mathrm{COM} 1$ (orange) strains in concentrated cell suspensions. The strains were grown at $98^{\circ} \mathrm{C}$ and then incubated at $60^{\circ} \mathrm{C}$ for $72 \mathrm{~h}$ after which a $200 \mathrm{x}$ concentrated cell suspension $\left(\geq 10^{10}\right.$ cells $\left./ \mathrm{mL}\right)$ was prepared in the presence of maltose and incubated at $60^{\circ} \mathrm{C}$ to assess product formation. 
Figures

Figure a
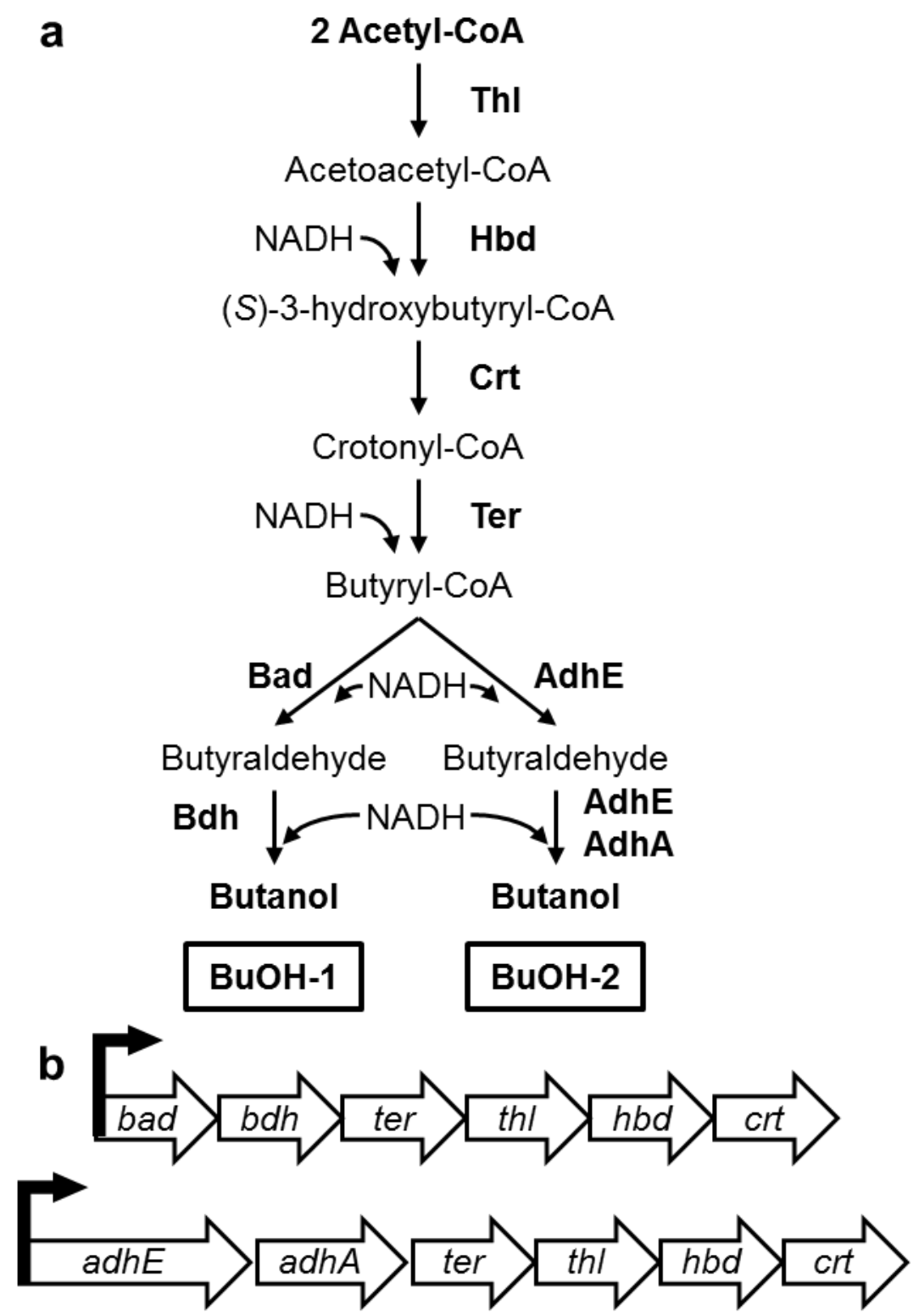
Figure 2
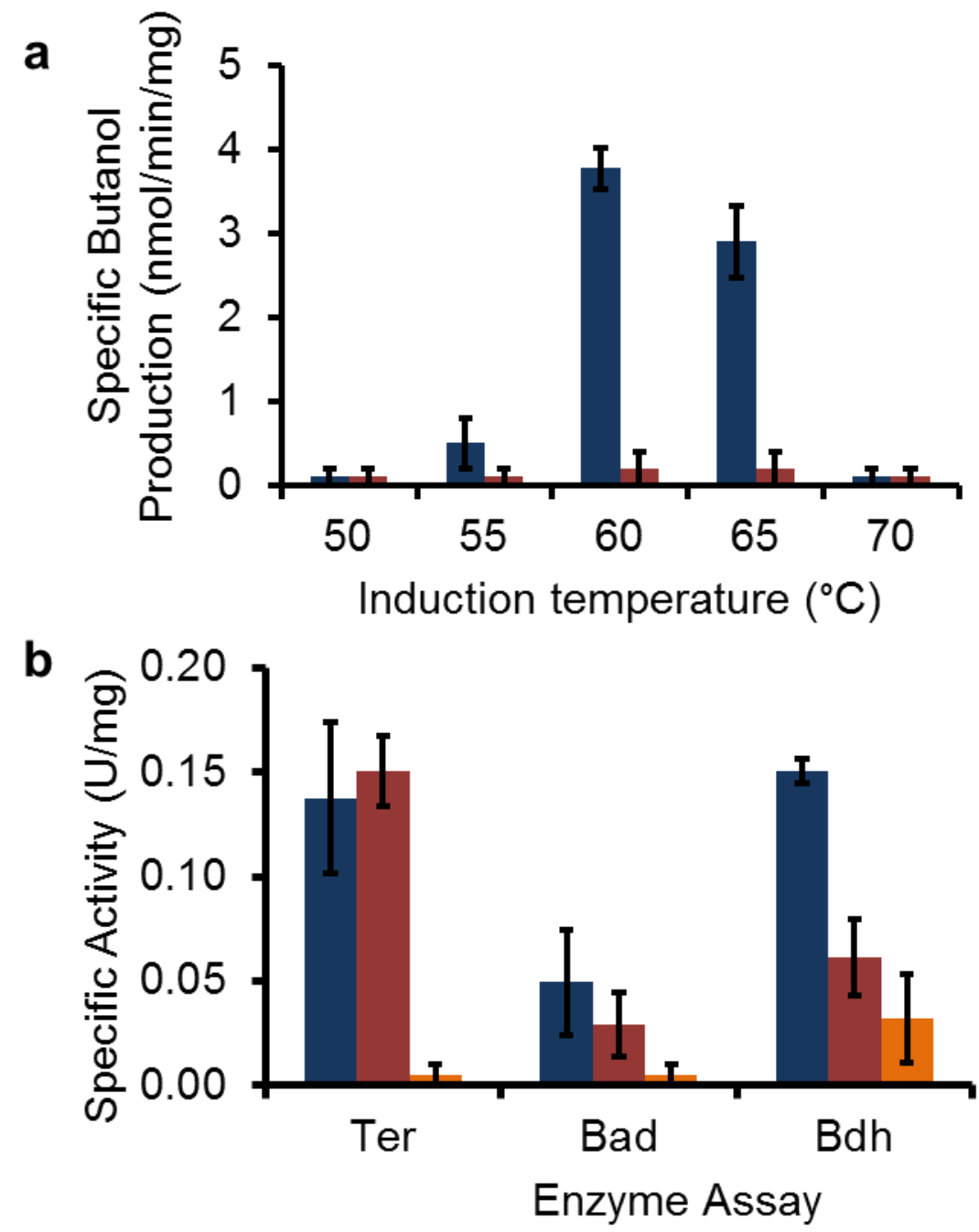
Figure 3
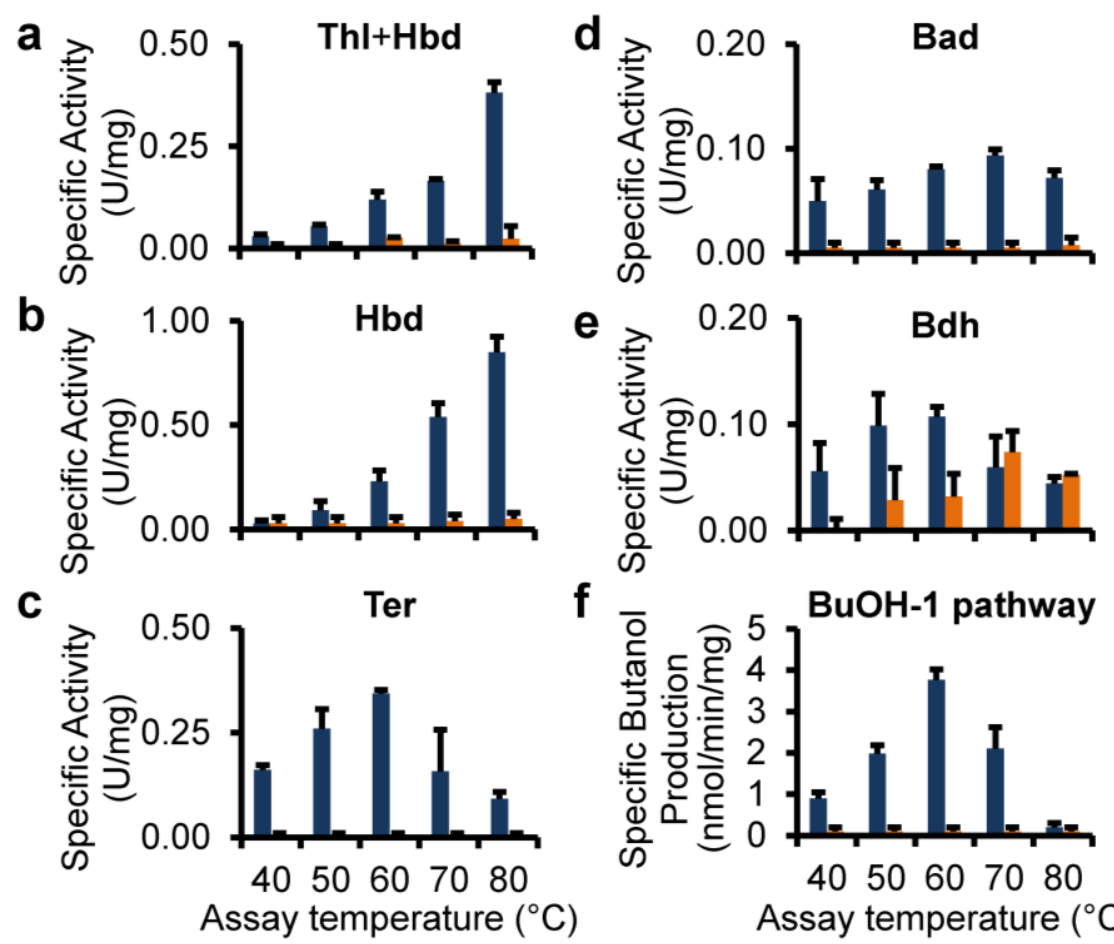

$f$ $\overline{0}$ BuOH-1 pathway

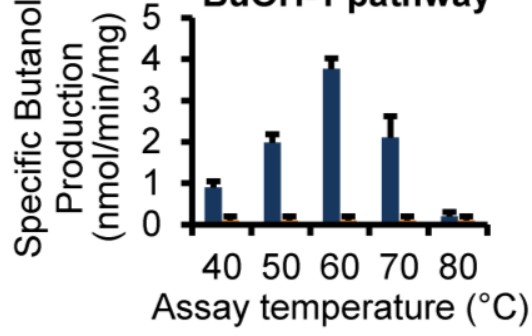


Figure 4

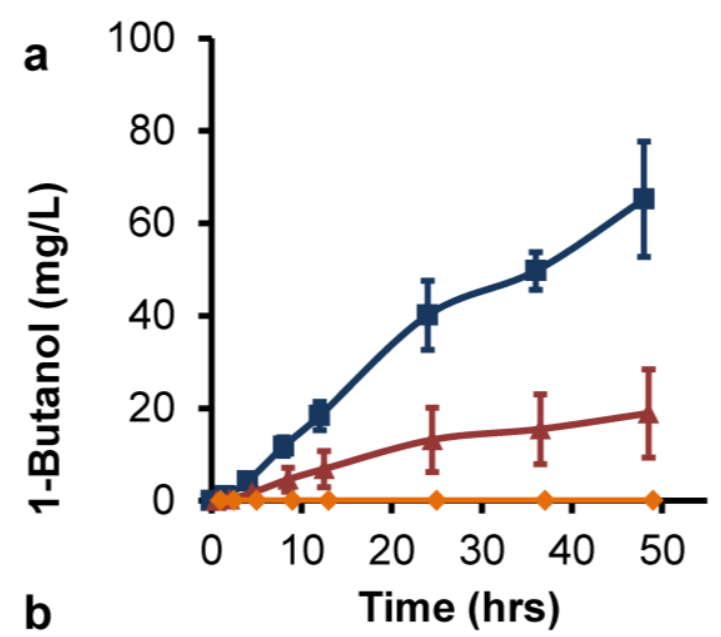

b
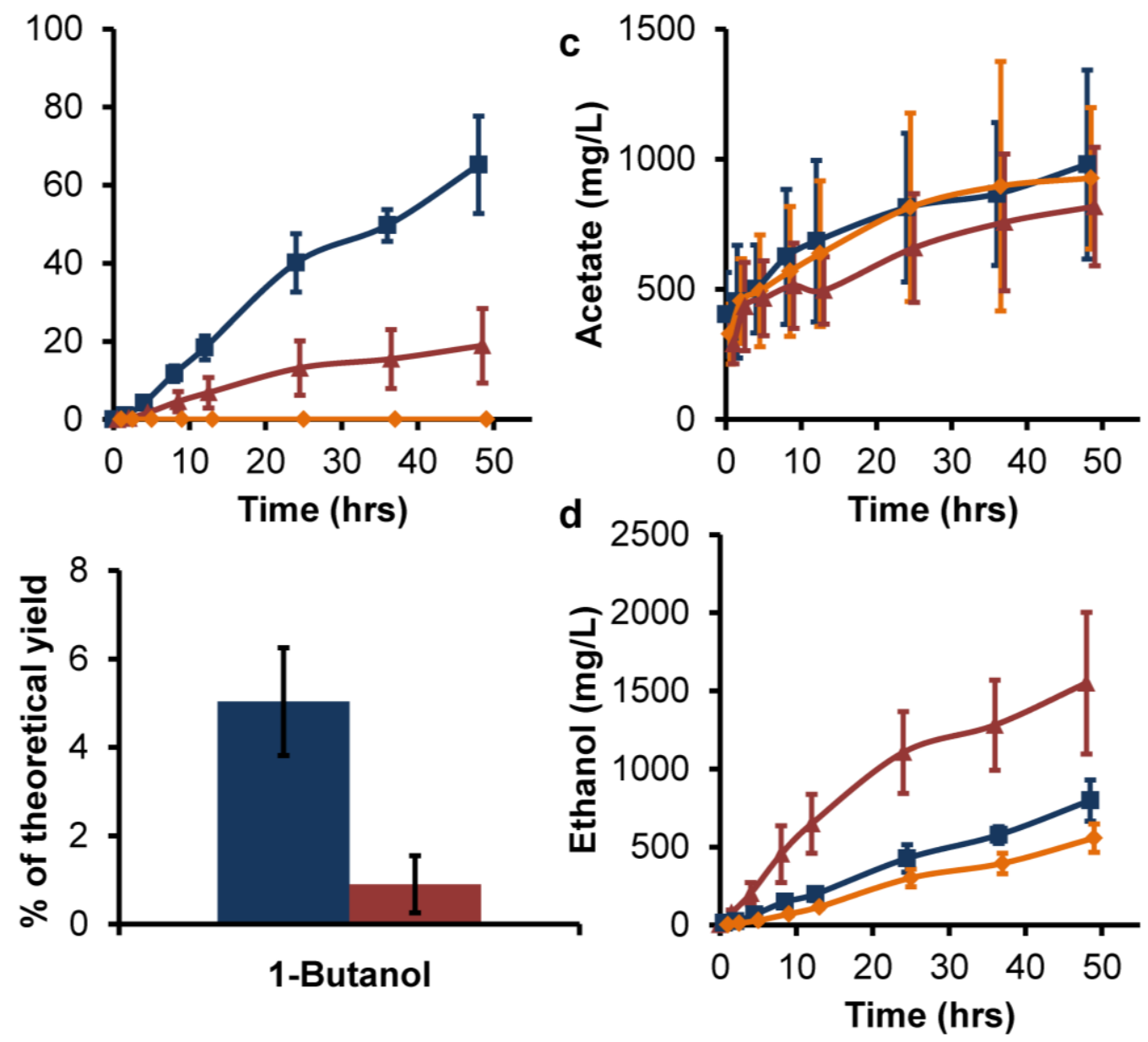